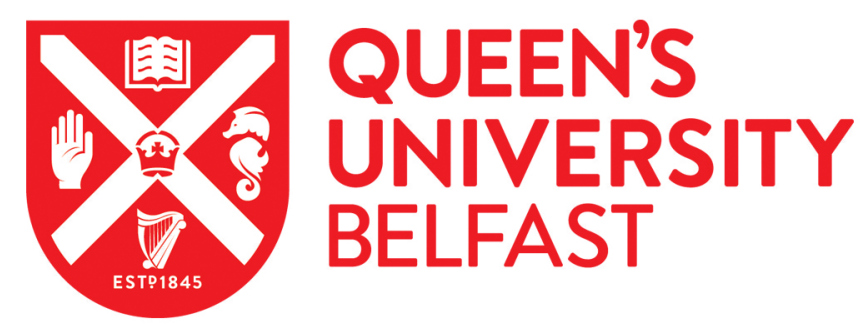

\title{
Towards a Contextual Definition of Rape: Consent, Coercion and Constructive Force
}

Dowds, E. (2019). Towards a Contextual Definition of Rape: Consent, Coercion and Constructive Force. The Modern Law Review, 83(1), 35. https://doi.org/10.1111/1468-2230.12461

\section{Published in:}

The Modern Law Review

\section{Document Version:}

Peer reviewed version

\section{Queen's University Belfast - Research Portal:}

Link to publication record in Queen's University Belfast Research Portal

\section{Publisher rights}

( 2019 The Author. The Modern Law Review @ 2019 The Modern Law Review Limited. This work is made available online in accordance with the publisher's policies. Please refer to any applicable terms of use of the publisher.

\section{General rights}

Copyright for the publications made accessible via the Queen's University Belfast Research Portal is retained by the author(s) and / or other copyright owners and it is a condition of accessing these publications that users recognise and abide by the legal requirements associated with these rights.

Take down policy

The Research Portal is Queen's institutional repository that provides access to Queen's research output. Every effort has been made to ensure that content in the Research Portal does not infringe any person's rights, or applicable UK laws. If you discover content in the Research Portal that you believe breaches copyright or violates any law, please contact openaccess@qub.ac.uk. 


\title{
$\underline{\text { Towards a contextual definition of rape: Consent, coercion and constructive force }}$
}

\begin{abstract}
This paper considers 'consent-based' and 'coercion-based' models of defining rape. It argues that the ability of these models to adequately protect against violations of sexual autonomy is dependent on their engagement with the broader circumstances within which sexual choices are made. Following an analysis of both models it is argued that attempts to contextualise consent and coercion are often undermined by evaluative framings that encourage scrutiny of the complainant's actions at the expense of a thorough engagement with the broader circumstances. This is particularly problematic where rape occurs as a result of non-violent coercion and the victim does not verbally or physically demonstrate their lack of consent. The paper draws from United States Military law to provide a way forward. It argues that the doctrine of constructive force, which has been used to deal with instances of non-violent coercion in these contexts, has the potential to progressively reshape our contextual and evaluative framings in domestic contexts.
\end{abstract}

Keywords: Rape; Definition; Consent; Coercion; Sexual Autonomy; Constructive Force.

\section{Introduction}

The concept of sexual autonomy has played a key role in enhancing our understanding of the wrong of rape. ${ }^{1}$ Encompassed within this concept is the idea that individuals have the right to make autonomous decisions about their sex lives. Conceptualising rape as a violation of sexual autonomy has been central to establishing consent, as opposed to force and resistance, as core to definitional constructions of the offence. This position has been endorsed by the European

\footnotetext{
${ }^{1}$ See e.g., SJ Schulhofer, 'Taking Sexual Autonomy Seriously: Rape Law and Beyond' (1992) 11 Law and Philosophy 35 and V Munro, 'Constructing Consent: Legislating Freedom and Legitimising Constraint in the Expression of Sexual Autonomy' (2008) 41 Akron Law Review 923.
} 
Court of Human Rights (ECtHR). ${ }^{2}$ The Committee on the Elimination of Discrimination against Women (CEDAW) has even proposed two models of rape law, a positive or active model of rape law which centres around the existence or non-existence of 'unequivocal and voluntary agreement' and the other framed in more negative terms requiring that the act take place in 'coercive circumstances'. These two models are commonly referred to as 'consentbased' or 'coercion-based' models of rape and variations of them exist in several domestic jurisdictions. ${ }^{3}$ Although framed differently, both of these models are said to retain consent at the centre. ${ }^{4}$ However, research on the application of rape law has shown a tendency for narratives of force and resistance to re-emerge in court processes, with judges, barristers and juries casting suspicion on complainants who do not physically or verbally resist. ${ }^{5}$ Consequently, scholars such as Kelly and Munro have emphasised the importance of engaging

\footnotetext{
${ }^{2}$ M.C v Bulgaria (Application no. 39272/98) 4 December 200.

${ }^{3}$ Short hand language for these models adopted from K. Grewal, 'The Protection of Sexual Autonomy under International Criminal Law: The International Criminal Court and the Challenge of Defining Rape', (2012) 10 Journal of International Criminal Justice 373. For an overview of models in European context see European Institute for Gender Equality, Analysis of the National Definitions of Rape, October 2016 and Amnesty International, Right to be free from Rape: Overview of Legislation and State of Play in Europe and International Human Rights Standards, 19 January 2018 Internal Index No: EUR 01/7757/2018.

${ }^{4}$ Vertido $v$ The Philippines (Communication No. 18/2008) Committee on the Elimination of Discrimination against Women July 2010; Council of Europe, Council of Europe Convention on Preventing and Combating Violence Against Women and Domestic Violence, 11 May 2011.

${ }^{5}$ See e.g., R. Burgin, Persistent Narratives of Force and Resistance: Affirmative Consent as Law Reform, (2018) The British Journal of Criminology 1; L. Ellison and V. Munro, 'Better the devil you know? 'Real rape' stereotypes and the relevance of a previous relationship in (mock) juror deliberations (2013) 17(4) International Journal of Evidence \& Proof 299.
} 
critically with the circumstances under which choices are made to take account of the 'continuum of coercion' within which the crime of rape may occur. ${ }^{6}$

While acknowledgment of the need for a more contextual approach to rape is welcomed, there has, to date, not been a comparison of the precise analytical tools that may be deployed under both models of rape law. This paper addresses this gap by examining the definitions of rape in England and Wales and Canada as examples of the consent-based approach, and Michigan and Italy as examples of the coercion-based approach. ${ }^{7}$ These jurisdictions have been chosen due to the variation in their approaches in relation to how the elements of consent and coercion are treated for the purpose of the mens rea and actus rea of the offence. ${ }^{8}$ Although some

${ }^{6}$ L. Kelly, 'The Continuum of Sexual Violence', in J Hanmer and M Maynard (eds) Women, Violence and Social Control, (Michigan: Palgrave Macmillan 1987) 46; V. Munro, 'An Unholy Trinity? Non-Consent, Coercion and Exploitation in Contemporary Legal Responses to Sexual Violence in England and Wales' (2010) 63(1) Current Legal Problems 45, 46.

${ }^{7}$ This methodology is similar to what Adams called a 'representative comparison' which involves selecting at least two representatives from identified groups, see A. Adams, 'The First Rape Prosecution before the ICC: Are the Elements of Crimes Based on a Source of International Law? (2015) 15 International Criminal Law Review 1098, 1102. While it is acknowledged that there is variation beyond these definitions the selected jurisdictions allow for a consideration of the interplay between consent and coercion.

${ }^{8}$ For some background see, United Kingdom Home Office, Setting the Boundaries: Reforming the law on sex offences, 1 July 2000; L. Vandervort, Affirmative Sexual Consent in Canadian Law, Jurisprudence, and Legal Theory (2012) 23(2) Columbia Journal of Gender and Law 395; J. Temkin, Rape and The Legal Process, (Oxford: Oxford University Press, 2002) on the 'famed' Michigan model; R.A. Fenton, Rape in Italian Law: Towards the Recognition of Sexual Autonomy' in in C. McGlynn, and V. Munro, (eds) Rethinking Rape Law: International and Comparative Perspectives (London: Routledge 2010). 
commentators have emphasised a division between the two models, ${ }^{9}$ this analysis will demonstrate that the more either model addresses the context within which a sexual encounter takes place, the more substantively aligned the two models become. Nonetheless, it is argued that the models in England and Wales and Canada, where the element of consent is explicitly included and defined in the applicable law, are preferable. This is because the legislative definition of rape in these jurisdictions more clearly reflect rape as a violation of sexual autonomy and provide a more precise definition in line with the important legal principle of nullum crimen, nulla poena sina lege. ${ }^{10}$

In advocating such an approach, the author is aware of the on-going difficulties associated with consent-based definitions of rape, especially when a victim offers what could be described as 'apparent' ${ }^{11}$ or 'survival consent'. ${ }^{12}$ This may be relevant in the context of, for example, severe poverty, familial or intimate abuse, economic oppression or other abusive circumstances. As noted by Munro, discussing the England and Wales context, although 'the courts have begun to grapple with some of these issues within the confines of individual cases...clear principles capable of broad application have yet to emerge'. ${ }^{13}$ In light of these ongoing challenges under the consent-based model, the article draws from military law on rape, in particular, the doctrine of constructive force utilised in United States (US) military law to provide a way forward. This

\footnotetext{
${ }^{9}$ For a discussion of some of the arguments based on a distinction between the two models see V. Munro, 'From Consent to Coercion: Evaluating International and Domestic Framework for the Criminalization of Rape' in McGlynn and Munro ibid.

${ }^{10}$ A Mokhtar, 'Nullum Crimen, Nulla Poena Sine Lege: Aspects and Prospects' (2005) 26 Statute Law Review 41.

${ }^{11} R v A C$ [2012] EWCA Crim 2034

12 J Pearce, 'A Social Model of "Abused Consent"' in M. Melrose and J. Pearce, Critical Perspectives on Child Sexual Exploitation (UK: Palgrave Macmillan 2013)

${ }^{13}$ Munro n 6 above 51.
} 
doctrine has evolved to take account of the 'unique situation of dominance and control' that may be present in certain military relationships or environments and its impact on the autonomy of the complainant. ${ }^{14}$ According to Murphy, it represents an approach that is 'analytically superior to its civilian counterparts' in dealing with sexual coercion not amounting to physical force. ${ }^{15}$ As such, it is argued that this doctrine provides a useful tool to bring some clarity and coherence to this area of law. ${ }^{16}$ While the discussion here is limited to the crime of rape, the analytical tools developed therein may be extended to other forms of gendered and sexualised violence. Indeed, the thorny issues surrounding autonomy, consent, constraint and coercion are apparent in the context of sex trafficking, ${ }^{17}$ forced marriage, ${ }^{18}$ prostitution, ${ }^{19}$ 'survival sex',${ }^{20}$ sexual exploitation and abuse by peacekeeping forces. ${ }^{21}$ All of these abuses involve some sort

\footnotetext{
${ }^{14}$ United States v. Bradley, 28 M.J. 197, 200 (C.M.A. 1989).

15 T. Murphy, 'A matter of force: The redefinition of rape' (1996) 39(19) Air Force Law Review.

${ }^{16}$ The author is under no illusions about the inadequacies of military law approaches to sexual violence: S. Cernak, 'Sexual Assault and Rape in the Military: The Invisible Victims of International Gender Crimes at the Front Lines' (2015) 22 Michigan Journal of Gender and Law 207. However, it will be argued that there are novel approaches
} to the crime of rape that can be utilised by domestic states.

${ }^{17}$ J. Elliot, The Role of Consent in Human Trafficking (Abingdon: Routledge 2014).

18 A. Bunting, B.N. Lawrance, and R.L. Roberts (eds.), Marriage by Force?: Contestation over Consent and Coercion in Africa, (USA: Ohio University Press, 2016).

${ }^{19}$ Y. Peng, "Of course they claim they were coerced": On voluntary prostitution, contingent consent, and the modified whore stigma' (2005) 7(2) Journal of International Women's Studies, 17.

${ }^{20}$ V.A. Forro 'Survival Sex' in S. Loue (ed) Mental Health Practitioner's Guide to HIV/AIDS (New York: Springer 2013) 409.

${ }^{21}$ M. Henry, 'Sexual exploitation and abuse in un Peacekeeping Missions: Problematising Current Responses', in S. Madhok, A. Phillips, and K. Wilson (eds) Gender, Agency, and Coercion (UK: Palgrave Macmillan, 2013), 127. 
of power asymmetry or other hierarchical circumstances of compulsion which may benefit from the analytical tools developed in this paper.

The paper proceeds as follows. The first section will situate continuing expectations of force and resistance within the 'real-rape' stereotype and contrast this stereotypical understanding of rape with the conceptualisation of rape as a violation of sexual autonomy. The second section considers the definition of rape under different legal models. It draws on human rights law and the development of two dominant models of rape law to demonstrate the way in which the abstract notion of sexual autonomy may be translated into concrete legal rules. This section also undertakes a comparative analysis of these models in the selected jurisdictions of England and Wales, Canada, Michigan and Italy. The third section draws upon US military law on rape in order to clarify the relationship between consent and coercion and to propose a new approach. The final section concludes.

\section{CHALLENGING PERCEPTIONS OF 'REAL-RAPE': RAPE AS A VIOLATION OF SEXUAL AUTONOMY}

According to Reiten, rape is an 'essentially contested concept', open to differing and conflicting interpretations. ${ }^{22}$ Such concepts often have clear paradigmatic cases, which everyone would agree falls within the concept, and borderline cases, which may fall within some but not all interpretations. ${ }^{23}$ Estrich introduced the term 'real-rape' in the 1970 s to describe the dominant stereotype around what constitutes rape and who might be convincingly

\footnotetext{
${ }^{22}$ E. Reiten, 'Rape as an Essentially Contested Concept' (2001) 16(2) Hypatia 43-66.

${ }^{23}$ Ibid, 49.
} 
labelled a victim. ${ }^{24}$ This stereotype involves a young virginal victim who is violently attacked at night by a stranger; she resists but is overpowered and raped sustaining multiple injuries. ${ }^{25}$ It can be contrasted with what has been termed 'simple rape': rape that occurs within homes by a friend, a family member, a partner or an acquaintance, with no obvious signs of violence or resistance. ${ }^{26}$ Evidence demonstrates that the latter form of rape is more prevalent than the former, ${ }^{27}$ and that victims may respond to the attack in various ways, from freezing to flopping to trying to befriend the attacker. ${ }^{28}$ Yet dominant acceptance and internalisation of the "realrape' stereotype works to effectively disqualify these experiences. This effect is reflected in a 2016 European Commission survey which found that although $86 \%$ of respondents believed that violence against women was most likely to occur within the home, one-third of respondents considered that sexual intercourse without consent may be justified 'in certain circumstances', these included not saying 'no' clearly or not fighting back (both 10\%). ${ }^{29}$

\footnotetext{
${ }^{24}$ S. Estrich, Real Rape: How The Legal System Victimizes Women Who Say No (Cambridge: Harvard University Press, 1987), 5.

${ }^{25}$ Ibid, $1-5$

${ }^{26}$ Ibid, 5 .

${ }^{27}$ According to the Rape, Abuse \& Incest National Network (RAINN), for instance, in the United States 7 out of 10 rapes are carried out by someone known to the victim https://www.rainn.org/statistics/perpetrators-sexualviolence (last visited 23 May 2018); In the United Kingdom, Rape Crisis for England and Wales notes that approximately $90 \%$ of those who are raped know the perpetrator prior to the offence, https://rapecrisis.org.uk/statistics.php (last accessed 23 May 2018).

28 See e.g., Z. Lodrick, 'Psychological Trauma - What Every Trauma Worker Should Know' at http://www.zoelodrick.co.uk/training/article-1 (last accessed 18 November 2018); N Sugar, D Fine and T Eckert, 'Physical Injury After Sexual Assault: Findings of a Large Case Series' (2004) 190 American Journal of Obstetrics and Gynaecology 71-6.

${ }^{29}$ European Commission, Special Eurobarometer 449 Report Gender-based violence, November 2016, 6-7.
} 
Such perceptions have also infiltrated criminal justice systems, with victims who do not fit the dominant perception of how a 'real' victim should react being subject to intrusive questioning and treated with suspicion. ${ }^{30}$ For instance, a 2015 report into the handling of rape cases in London found that cross-examination by the defence often focused on a victim's lack of resistance: 'Why did they not fight back? What prevented them from shouting out to attract help or even ask for help from others in the very same room?' ${ }^{31}$ In Canada, Comack found that judicial decisions continue to reflect rape myths and recently a Canadian judge was forced to resign following his treatment of a rape complainant in which he asked her why she 'could not just keep your knees together'. ${ }^{32}$ Burgin found similar practices in Victoria with one defence barrister asking a complainant whether she thought her behaviour was 'strange' and 'irrational' because she froze rather than scream or fight back. ${ }^{33}$ Unsurprisingly, this type of questioning can be effective from the defences' point of view. Research on mock juries carried out by Ellison and Munro, for instance, found that in cases where women were perceived as giving mixed signals, the need for strong physical resistance featured heavily in jury deliberations. ${ }^{34}$

\footnotetext{
${ }^{30}$ J. Du Mont, K. Miller and T.L. Myhr, 'The Role of "Real Rape" and "Real Victim" Stereotypes in the Police Reporting Practices of Sexually Assaulted Women’ (2003) 9(4) Violence Against Women 466.

${ }^{31}$ Rt Hon Dame Elish Angiolini DBE QC, Report of the Independent Review into The Investigation and Prosecution of Rape in London, 30 April 2015 at https://www.cps.gov.uk/sites/default/files/documents/publications/dame_elish_angiolini_rape_review_2015.pdf (last accessed 7 April 2019).

${ }^{32}$ E. Comack, Locating Law: Race/Class/Gender Connections (Halifax: Fernwood Publishing, 1999); A. Wooley, 'The resignation of Robin Camp: background and reflections from Canada' (2017) 20(1) Legal Ethics 134.

${ }^{33}$ Burgin $n 5$ above 11.

${ }^{34}$ Ellison and Munro $n 5$ above.
} 
The way in which these myths and stereotypes play out in the adversarial court process has led some to describe the rape trial as the victim's 'second assailant'. ${ }^{35}$ Research suggests that victims who have a negative experience within the criminal justice system, due to a lack of sensitivity or victim-blaming attitudes for example, may suffer a detrimental impact on their overall wellbeing. ${ }^{36}$ However, despite these challenges and experiences, criminal trials remain a vital forum for addressing the crime of rape, as reflected in the visible increase in reporting of rape to the police. For instance, 121,187 sexual offences were recorded by the police in England and Wales in the year ending March 2017, an increase of 14\% on the year before, and in 2017 official reports in the United States recorded a 19.4 percent increase in the number of reported rapes since $2013 .{ }^{37}$

The persistence of narratives of force and resistance can be linked to regressive interpretations of rape that view it as crime of violence in the narrowest of terms. ${ }^{38}$ This view can be contrasted with more contemporary understandings of rape that consider it to be a violation against

\footnotetext{
${ }^{35}$ E. Stanko, Intimate Intrusions: Women's Experience of Male Violence (Oxon: Routledge Revivals 2013) 83.

${ }^{36}$ See e.g., M. Burman, 'Evidencing sexual assault: Women in the witness box' (2009) 56(4) Probation Journal 1-20; U. Orth, 'Secondary Victimization of Crime Victims by Criminal Proceedings' (2001) 15(4) Social Justice Research 313-325,

37 Office for National Statistics, Sexual offences in England and Wales: year ending March 2017 at https://www.ons.gov.uk/peoplepopulationandcommunity/crimeandjustice/articles/sexualoffencesinenglandandw ales/yearendingmarch2017 (last accessed 6 April 2019); Federal Bureau of Investigation, Criminal Justice Information Service Division, 2017 Crime in the United States Report at https://ucr.fbi.gov/crime-in-theu.s/2017/crime-in-the-u.s.-2017 (last accessed 6 April 2019).

${ }^{38}$ See e.g., C.L. Muehlenhard, S. Danoff-Burg, \& I.C. Powch, 'Is rape sex or violence? Conceptual issues and implications' in D. M. Buss \& N. M. Malamuth (eds.), Sex, power, conflict: Evolutionary and feminist perspectives (New York: Oxford University Press 1996) 119-137
} 
individual sexual autonomy. ${ }^{39}$ Although the latter view is not without its detractors, ${ }^{40}$ sexual autonomy has been explicitly stated as the guiding principle underpinning rape law in some domestic jurisdictions as well as at the international level. ${ }^{41}$ The concept refers to the 'freedom to determine one's own sexual experiences, to choose how and with whom one expresses oneself sexually, ${ }^{42}$ According to Schulhofer, it has two dimensions: positive sexual autonomy which provides that every adult should be free to decide for themselves what sort of sex to engage in and; negative sexual autonomy which provides that individuals have the right to safeguard themselves against, and to exclude, any and all unwanted sex. ${ }^{43}$ Rape law is tasked with striking the appropriate balance between the two facets, respecting expressions of positive sexual autonomy and protecting individuals from violations of their negative sexual autonomy when such violations are sufficiently serious to warrant criminal intervention. In striking this balance, attention must be paid to a third dimension of sexual autonomy, what could be described as its contextual dimension. This dimension forces an analysis of the broader

\footnotetext{
${ }^{39}$ See e.g., Schulhofer and Munro n 1.

${ }^{40}$ See for instance, N. Lacey, 'Unspeakable Subjects, Impossible Rights: Sexuality, Integrity and Criminal Law' (1998) 11 Canadian Journal of Law and Jurisprudence 47; J.J. Fischel and H.R. O'Connell, 'Disabling Consent, or Reconstructing Sexual Autonomy’ (2015) 30(2) Columbia Journal of Gender and Law 428.

${ }^{41}$ See for instance, domestic reform documents: United Kingdom Home Office n 37 above (please provide the correct cross reference); Scottish Law Commission, Report on Rape and Other Sexual Offences, December 2007. International cases: Prosecutor v. Kunarac, Kovač and Vuković, case no. IT-96-23, judgment of 22 February 2001 (ICTY)); M.C v Bulgaria n 6 above (ECtHR). International bodies: United Nations, Handbook for Legislation on Violence Against Women, Department Economic and Social Affairs Division for the Advancement of Women, $2010,26$.

${ }^{42}$ S. Schulhofer, Unwanted Sex: The Culture of Intimidation and the Failure of the Law, (Cambridge: Harvard University Press 1998), 99.

${ }^{43}$ Ibid.
} 
circumstances under which a choice has been made to determine whether the conditions of autonomous consent have been breached or a criminal level of coercion has been at play. ${ }^{44}$

The recognition of a contextual dimension to sexual autonomy has the potential to take account of what Kelly has described as the 'continuum of coercion' within which the crime of rape may occur. $^{45}$ The continuum moves beyond the 'real-rape' stereotype by encompassing a range of behaviours, beyond physical force, that remove an individual's ability to control intimate contact. $^{46}$ Take for instance a domestically abusive relationship. While abuse in such a relationship may involve physical violence, it may get to a point where physical violence is no longer necessary to obtain sex. This is reflected in a study of women who sought refuge following domestic abuse, where one participant explained that after her husband violently bound her hands with a belt and 'had his way with her', she 'never said "no" to him again'. ${ }^{47}$ Such relationships may also involve more subtle forms of psychological abuse, such as those recognised in the offence of coercive or controlling behaviour. ${ }^{48}$ This includes acts of humiliation or intimidation used to harm, punish or frighten the victim or behaviour designed to make a person subordinate, by for instance, isolating them from sources of support or depriving them of the means needed for independence. ${ }^{49}$ In a relationship categorised by this

\footnotetext{
${ }^{44}$ Munro has previously described this dimension as 'evaluative' see Munro n 6 above 46. I would like to thank the anonymous reviewer for their suggestions in terms of refining this terminology.

${ }^{45}$ Kelly n 6 above 46.

${ }^{46}$ J. Mc Gregor 'The Legal Heritage of Rape' in J.M. Brown and S.L. Walklate, Handbook on Sexual Violence, (New York: Routledge 2011), 70.

${ }^{47}$ E. Stark, Coercive Control: How Men Entrap Women in Personal Life (Oxford University Press 2007) 243

${ }^{48}$ See for instance, The Council of Europe Convention on preventing and combating violence against women and domestic violence (Istanbul Convention) 2011; Section 76 Serious Crimes Act 2015.

${ }^{49}$ V. Bettinson, 'Coercive Control: In the Commission of Sexual Violence and Domestic Violence' (2017) 14 Contemporary Issues in Law 85.
} 
type of abuse, the perpetrator may have gained total control over the victim and the victim may thus become compliant with their demands. As noted by one participant in a study on survival techniques employed by women who had been abused by their partners: 'I just act however he wants me to act. I just go limp...I just shut up'. ${ }^{50}$ Another response to abuse may be to become an active, rather than passive, participant and even initiate sexual relations as a means to manage and control risk. ${ }^{51}$ As noted by one participant in a study on sex and sexual violation: 'there was one particular afternoon, he came back in a foul mood, and I knew he was gonna hit me, and I didn't wanna get hit, um, so I just jumped his bones instead' ${ }^{52}$

While the responses of these women may seem puzzling when viewed through a narrow force and resistance lens, a context-sensitive approach to rape, as required when viewed through the sexual autonomy lens set out above, allows us to think differently about these scenarios. In particular, it encourages us to engage with the background circumstances to determine whether, and to what extent, the participant's autonomous choices were constrained. At the same time, however, this approach raises challenges in terms of "where to draw the boundaries between bad, immoral and illegal sex'.53 These challenges become more pronounced when considered alongside the important legal principle of nullum crimen, nulla poena sina lege. ${ }^{54}$ This principle requires the law to be defined in a way that is sufficiently clear and precise; while absolute

\footnotetext{
${ }^{50}$ L. Lembert, 'Women's strategies for survival: Developing agency in abusive relationships' (1996) 11(3) Journal of Family Violence 269, 281.

51 Ibid.

${ }^{52}$ T. Palmer, 'Distinguishing Sex from Sexual Violation: Consent, Negotiation and Freedom to Negotiate' in A Reed and M Bohlander (eds), Consent: Domestic and Comparative Perspectives, (London: Routledge 2017$) 19$. ${ }^{53}$ Munro $n 6$ above 70.

${ }^{54}$ As enshrined in Article 7 of the Council of Europe's European Convention for the Protection of Human Rights and Fundamental Freedoms, as amended by Protocols Nos. 11 and 14, 4 November 1950.
} 
precision is not required, an individual must know from the wording of the relevant provision and, if need be, with the aid of legal advice, what conduct is prohibited. ${ }^{55} \mathrm{~A}$ fundamental question in this regard is how the contextual and evaluative analysis required under the sexual autonomy approach can be translated in concrete legal rules. In order to address this question, the next section evaluates the two dominant models for defining rape as advocated in human rights law and reflected in selected jurisdictions.

\section{DEFINING RAPE: THE DEVELOPMENT OF TWO MODELS}

In the 2003 case of M.C. v Bulgaria, the European Court of Human Rights (ECtHR) was confronted with a case where a 14 year-old girl had alleged that two men had raped her, but the Bulgarian authorities had terminated the investigation due to there being insufficient proof to show that she had been physically forced to have sex with the men. ${ }^{56}$ The applicant argued that the domestic legal framework, which required proof of physical resistance by the victim, and the practice of the Bulgarian authorities, constituted a violation of Bulgaria's positive obligations under the European Convention on Human Rights (ECHR). Specifically, the victim alleged a breach of Article 3, the prohibition of torture, and of Article 8, the right to respect for private and family life. In relation to Article 3, the ECtHR explained that States must take measures designed to ensure that individuals within their jurisdiction are not subjected to illtreatment, including ill-treatment administered by private individuals. ${ }^{57}$ Under Article 8 it was noted that positive obligations may involve the adoption of measures in the sphere of relations between individuals and that in the context of rape, 'where fundamental values and essential

\footnotetext{
${ }^{55}$ See e.g., Cantoni v France, (Application no. 17862/91) 11 November 1996, para 29.

${ }^{56}$ M.C. v. Bulgaria $\mathrm{n} 2$ above.

${ }^{57}$ European Convention n 54 above.
} 
aspects of private life are at stake', this requires efficient criminal-law provisions. ${ }^{58}$ As such it was asserted that States are obliged 'to enact criminal-law provisions effectively punishing rape and to apply them in practice through effective investigation and prosecution'. ${ }^{59}$

While acknowledging that States enjoy a wide margin of appreciation, the ECtHR explained that this is circumscribed by the ECHR provisions and, in interpreting them, the ECtHR must have regard to 'any evolving convergence' between Contracting States as to the standards to be achieved. ${ }^{60}$ Thus, following a survey of rape law in international and domestic law, the ECtHR endorsed the principle of sexual autonomy and declared that the requirement for resistance

risks leaving certain types of rape unpunished and thus jeopardising the effective protection of the individual's sexual autonomy. In accordance with contemporary standards and trends in that area, the member States' positive obligations under Articles 3and 8 of the Convention must be seen as requiring the penalisation and effective prosecution of any non-consensual sexual act, including in the absence of physical resistance by the victim. ${ }^{61}$

The ECtHR concluded that there is a 'universal trend towards regarding lack of consent as the essential element of rape and sexual abuse'. ${ }^{62}$ Furthermore, the ECtHR observed that, even where domestic frameworks refer to the use of violence and threats, as opposed to the absence

\footnotetext{
${ }^{58}$ M.C. v. Bulgaria $\mathrm{n} 2$ above, para 150.

${ }^{59}$ Ibid, para 153.

${ }^{60}$ Ibid, para 155.

${ }^{61}$ Ibid, paras 164-166 (emphasis added by author).

${ }^{62}$ Ibid, para 163.
} 
of consent, lack of consent remains central in the application of the law. ${ }^{63}$ As such, the ECtHR sought to provide fuller protection of sexual autonomy by placing an emphasis on lack of consent and acknowledging that a limited focus on violence and resistance is detrimental to the effective criminalisation and punishment of all forms of rape. ${ }^{64}$

In the 2010 case of Vertido $\mathrm{v}$ the Philippines, ${ }^{65}$ the Committee on the Elimination on the Discrimination against Women (CEDAW) was faced with a similar situation where the requirement for resistance had resurfaced and led to an acquittal at the Regional Court of Davao City, Philippines. In this case, a woman (the complainant) who worked for the Davao City Chamber of Commerce and Industry (the Chamber) in Davao City, claimed to have been raped by the former President of the Chamber (the accused). According to the facts, as presented by the complainant, on the night of the alleged rape the accused had given the complainant a lift home; however, rather than taking her home he brought her to a motel room. She hid in the bathroom of the motel and also tried to escape, but the accused caught her, held her down and the complainant alleged that he had raped her. Throughout the incident the complainant also thought the accused had a gun. While she had begged him to stop and had been unconscious through some of the encounter, the Regional Trial Court Davao City acquitted the accused noting that:

should the [complainant] really have fought off the accused when she had regained consciousness and when he was raping her, the accused would have been unable to

\footnotetext{
${ }^{63}$ Ibid, para 159.

${ }^{64}$ Echoed in Case of the Miguel Castro-Castro Prison v. Peru, Judgment of November 25, 2006 (Merits, Reparations and Costs) (Inter-American Court of Human Rights) para 306.

65 Vertido $n 3$ above.
} 
proceed to the point of ejaculation, in particular bearing in mind that he was already in his sixties. ${ }^{66}$

In reaffirming rape as a violation of women's right to personal security and bodily integrity, the CEDAW condemned the Davao City court's reliance on gender-based myths and asserted that the Philippines must review its definition of rape so as to place the lack of consent at its centre. ${ }^{67}$ The CEDAW further stated that this may be achieved by enacting a definition that either: 'requires the existence of "unequivocal and voluntary agreement" and requiring proof by the accused of steps taken to ascertain whether the complainant/survivor was consenting; or requires that the act take place in "coercive circumstances", including a broad range of circumstances' ${ }^{68}$ The former model will now be referred to as the consent-based model and the latter the coercion-based model.

Both models have subsequently been placed on an equal footing and used by the United Nations and non-governmental organisations, such as Equality Now, as a benchmark against which to

\footnotetext{
${ }^{66}$ Ibid, para 2.9.

${ }^{67}$ Ibid, para 8.9 (b)(ii). Article 266-A of the Revised Penal Code of the Philippines, as amended by Republic Act No. 8353 of 1997, reads "Rape: When and How Committed. Rape is committed: 1. By a man who shall have carnal knowledge of a woman under any of the following circumstances: (a) Through force, threat, or intimidation; (b) When the offended party is deprived of reason or otherwise unconscious; (c) By means of fraudulent machination or grave abuse of authority; and (d) When the offended party is under 12 years of age or is demented, even though none of the circumstances mentioned above be present. 2. By any person who, under any of the circumstances mentioned in paragraph 1 hereof, shall commit an act of sexual assault by inserting his penis into another person's mouth or anal orifice, or any instrument or object, into the genital or anal orifice of another person."

${ }^{68}$ Ibid.
} 
measure the effectiveness of domestic legal frameworks on rape. ${ }^{69}$ Yet, the models provided by the CEDAW are skeletal in nature and the precise way in which consent operates under both models is unclear. For instance, the consent-based model as articulated by the CEDAW represents a positive or active model of rape law. The emphasis is on establishing whether positive consent, as opposed to dissent, can be identified and whether the accused actively sought positive consent. Thus, going to both the mens rea and actus reus of the crime. Yet, there is no indication of what precisely is meant by 'unequivocal and voluntary agreement'. The second model, the coercion-based model, is again less specific. It is framed in negative terms, focusing on the circumstances under which the act must occur, thus going to the actus reus. While the CEDAW has emphasised the importance of consent, this element does not feature explicitly. In terms of mens rea, it might be assumed that consent will play a role, but again this role is not explicit. Nor is it clear whether knowledge of the coercive circumstances under which the acts takes place would be required as part of the mens rea of this second model. Commentary on the definition of rape contained within the Council of Europe Convention on Preventing and Combating Violence Against Women and Domestic Violence may be of assistance here. ${ }^{70}$ While the Convention defined rape with explicit reference to consent, its explanatory note provided that where the crime is defined with reference to force, coercion or other circumstances it must be interpreted in a way that encompasses the notion of a lack of

\footnotetext{
${ }^{69}$ United Nations n 41 above; Equality Now, The Worlds Shame the Global Rape Epidemic How Laws Around the World are Failing to Protect Women and Girls from Sexual Violence, February 2017. See however, Campaign by Amnesty International, 'Rape is rampant in Europe. That's why we need to talk about consent' https://www.amnesty.org/en/latest/campaigns/2018/11/rape-in-europe/ (last accessed 27 November 2018) and Amnesty International n 3 above.

${ }^{70}$ Council of Europe Treaty Series - No. 210, Explanatory Report to the Council of Europe Convention on preventing and combating violence against women and domestic violence.
} 
freely given consent. ${ }^{71}$ Such an interpretation could equally apply to the CEDAW models. The CEDAW models thus provide an initial framework with domestic jurisdictions in control of how they operationalise either model. In light of this, the next section provides a fuller exploration of these models in their domestic contexts.

\section{‘Consent-based' Models}

In England and Wales, Section 1 of the Sexual Offences Act 2003 prohibits sexual activity where that person does not consent and the perpetrator does not reasonably believe that they consent. ${ }^{72}$ In line with the human rights standards above, it further provides that in determining whether a belief is reasonable consideration will be given to all of the circumstances including any steps taken to ascertain consent. ${ }^{73}$ A definition of consent is provided at Section 74: 'a person consents if he agrees by choice, and has the freedom and capacity to make that choice' ${ }^{74}$ This definition is further illuminated through the inclusion of a number of rebuttable and conclusive presumptions at Sections 75 and 76 respectively. Rebuttable presumptions include, for example, where the defendant was using violence or threatened immediate violence against the complainant or a third person. ${ }^{75}$ Where the prosecution proves one or more of the instances set out in Section 75, it will be presumed that the victim did not consent and that the defendant knew that the victim did not consent. The defence may, however, produce evidence to rebut the prosecution's case. The conclusive presumptions include where the defendant intentionally

\footnotetext{
${ }^{71}$ Ibid, para 193.

${ }^{72}$ Section 1(1) Sexual Offences Act 2003 (United Kingdom).

${ }^{73}$ Section 1(2) Ibid.

${ }^{74}$ Section 74 Ibid.

${ }^{75}$ Section 75(2)(a) Ibid.
} 
deceived the complainant as to the nature or purpose of the relevant act. ${ }^{76}$ Once the prosecution proves any of the circumstances under the conclusive presumptions, it will have established that the victim did not consent and the perpetrator did not reasonably believe the victim consented.

Beyond the circumstances listed in the presumptions, the Crown Court Compendium provides a number of circumstances that may be used to prove the absence of consent, such as, submission, fear without the use of force, or oppression (eg, previous abuse) ${ }^{77}$ However, it will be for the jury to determine whether a person is to be considered as having lacked the freedom to make a choice. To assist the jury in this task the judge may offer tailored directions in relation to the actus reus explaining, for example, the difference between consent and mere submission:

A person consents to something if he/she agrees to it and is capable of making this choice, and is free to do so. In some situations consent may be given enthusiastically, but in other circumstances it is given with reluctance, but nevertheless it is still consent. However, when a person is so overcome by fear that he/she lacks any capacity either to give consent or to resist, that person does not consent but is submitting to what takes place OR Where however a person gives in to something against his/her free will, that is not consent but submission. ${ }^{78}$

The directions may also specify that it is not necessary for the prosecution to prove that the complainant was subjected to threats or violence, was overpowered, put up a struggle or told

\footnotetext{
${ }^{76}$ Section $76(2)(a)$ Ibid.

${ }^{77}$ Judicial College, The Crown Court Compendium Part I: Jury and Trial Management and Summing Up, June 2018, Chapter 20, 16-17.

${ }^{78}$ Ibid, 19-20.
} 
the defendant that that he/she did not consent. ${ }^{79}$ In this regard, consent or the absence thereof can be understood as a state of mind..$^{80}$

While such directions are helpful and tackle problematic stereotypes, some complicated jurisprudence has developed in cases where, as a result of previous abuse or grooming, prima facie consent appears to have been given. The Court of Appeal has had to revisit statements made by judges in the Crown Court such as 'just where the line is to be drawn between real consent and submission, albeit willing submission, may not be easy to draw' ${ }^{81}$ and 'submission of her free choice to a demand made physically or in words, is not the same as consent... On the other hand, an exercise of free choice, if it led to reluctant agreement, that is not the same as submission'. ${ }^{82}$ Language of 'free choice' and 'willingness' is problematically used when describing both reluctant agreement, which would amount to consent, and submission, which would not. The potential for confusion in relation to these terms is intensified when situated within problematic socio-sexual scripts of seduction which view men, predominately, as the sexual initiator or even 'aggressor' and place women in a passive or submissive role. ${ }^{83}$ Indeed, following ten months of court observations in England and Wales, Smith and Skinner note that defence barristers often 'prioritised an examination of how victim/survivors removed consent instead of how accused men gained it' ${ }^{84}$ Although the statutory requirement to consider steps

\footnotetext{
79 Ibid.

${ }^{80}$ Supports judicial statements made in $R$ v Olubgoja, [1982] QB 320, 5.

${ }^{81} R$ v Kirk and another (2008) EWCA Crim 434 para 91-92 (emphasis added by author)

${ }^{82} R$ v Jeffrey (2017) EWCA Crim 469 para 25-28 (emphasis added by author)

${ }^{83}$ See e.g., H. Frith, 'Sexual scripts, sexual refusals and rape’ In M. Horvath and J. Brown (eds) Rape: Challenging contemporary thinking. (Willan Publishing 2009) 99-122.

${ }^{84}$ O. Smith and T. Skinner, 'How rape myths are used and challenged in rape and sexual assault trials' (2017) 26(4) Social and Legal Studies 441, 451.
} 
taken by the accused to ascertain consent when determining the mens rea of reasonable belief in consent is supposed to redirect this focus, the Crown Court Compendium provides that the defendant is not obliged to take steps. ${ }^{85}$ As such, confusion over the relationship between consent, coercion and submission may lead a jury to assume sexual interest or reasonable belief in consent, unless there are clear signs of resistance.

In light of the challenges associated with establishing belief in consent, some jurisdictions, including Canada, have adopted more affirmative conceptions of consent. While consent is understood as a state of mind in relation to the actus reus and defined similarly to England and Wales, as 'voluntary agreement' with a number of consent negating circumstances included, ${ }^{86}$ the Canadian Supreme Court has provided that 'the mens rea of sexual assault is not only satisfied when it is shown that the accused knew that the complainant was essentially saying "no", but is also satisfied when it is shown that the accused knew that the complainant was essentially not saying "yes" ${ }^{87}$ This interpretation of the law is akin to what has been termed the 'equality approach' in international human rights law which starts from the premise that

Women do not walk around in a state of constant consent to sexual activity unless and until they say 'no', or offer resistance to anyone who targets them for sexual activity. The right to physical and sexual autonomy means that they have to affirmatively consent to sexual activity. ${ }^{88}$

\footnotetext{
${ }^{85}$ Crown Court Compendium n 77 above, 16.

${ }^{86}$ Section 273.1 (1) and Section 265(3) of the Canadian Criminal Code 1985.

${ }^{87} R$ v Park (1995) 2 S.C.R. 836, para 39.

${ }^{88}$ Submission of Interights to the European Court of Human Rights in the case of M.C. v Bulgaria $\mathrm{n} 2$ above, para 12.
} 
The significance of this approach lies in the shift in focus: it requires consideration of whether there were active signals of agreement rather than simply looking for narrow and stereotypical indications of refusal. An affirmative consent standard has also been incorporated into the defence of honest, but mistaken, belief in consent, which is allowed in Canada but only where it has an 'air of reality'; that is, it raises a real issue that could go before the jury. ${ }^{89}$ In considering this defence, jurors are instructed to ask 'whether (the defendant) honestly believed that (the complainant) effectively said yes through his/her words or actions' and the defendants belief alone will not be enough where the complainant 'did not express that desire' ${ }^{90}$ In line with legislation in England and Wales, this belief will be assessed in light of whether the defendant took reasonable steps in the circumstances known to them to ascertain consent.

In reflecting on these definitions from a sexual autonomy perspective, the three dimensions identified in the previous section of this article are clearly identifiable. First, the inclusion of a positive definition of consent recognises individuals as moral agents and their right to control their sexual choices, ${ }^{91}$ thus reflecting the positive dimension of sexual autonomy. Second, the negative aspect of sexual autonomy is addressed through the prohibition of non-consensual contact and the inclusion of a list of circumstances that undermine consent. Third, the contextual dimension is built into the definitions through the use of concepts such as freedom and voluntariness, as well as a consideration of the surrounding circumstances. In England and Wales this dimension is acknowledged by directions attempting to delineate the relationships between consent, which can be given reluctantly, and submission. Such directions reflect an

\footnotetext{
${ }^{89}$ Park n 87 para 20.

${ }^{90}$ National Judicial Institute, Model Jury Instructions: Offence 271 Sexual Offence available at https://www.njiinm.ca/index.cfm/publications/model-jury-instructions/ (last visited 19 November 2018).

${ }^{91}$ See for instance Gardner and Shute, 'The Wrongness of Rape' in J Horder (ed), Oxford Essays in Jurisprudence: Fourth Series (Oxford: Oxford University Press 2000).
} 
understanding that there are pressures and constraints in everyday life that affect sexual decision making, not all of which will be criminal. ${ }^{92}$ However, the framing of these directions tend to invite a disproportionate focus on the actions or inactions of the complainant, rather than on the behaviour of the defendant. In this regard, a lack of resistance on the part of the complainant, for example, may then be used to bolster claims of reasonable belief in consent. It is thus arguable that the adoption of an active consent threshold in Canada moves standards forward by avoiding situations where consent is implied through silence or lack of resistance. Although not universally endorsed, ${ }^{93}$ there is a visible trend towards this approach within other jurisdictions. For example, Iceland and Sweden have recently reformulated their statutory definitions of consent so that it must be voluntarily or willingly 'expressed" ${ }^{\text {'4 }}$ and other jurisdictions are considering this reform. ${ }^{95}$

However, it is unclear whether the affirmative approach requires some manifestation of consent under both the actus reus and the mens rea of the crime. ${ }^{96}$ Further, while an affirmative consent standard might be beneficial to complainants in situations where they freeze or flop, it could be problematic in situations where the complainant is an active participant and thus appears to

\footnotetext{
92 See e.g., Munro n 1 and 6 above and S. Anderson, 'On Sexual Obligation and Sexual Autonomy’ (2013) 28(1) Hypatia 122.

${ }^{93}$ For an overview of arguments see J. Witmer-Rich, 'Unpacking Affirmative Consent: Not as Great as You Hope, Not as Bad as You Fear' (2016) 49 Texas Tech Law Review, 57-88.

${ }^{94}$ See e.g., Criminal Code 1940 (Iceland) art 194 and The Swedish Penal Code (1962) ch 6 s 1.

${ }^{95}$ See e.g., New South Wales Law Reform Commission, Consultation Paper 21: Consent in Relation to Sexual Offences, October 2018 and Law Reform Commission of Ireland, Issues Paper Knowledge or Belief Concerning Consent in Rape Law, 2018.

${ }^{96}$ Compare the approach under Canadian law with, for instance, the Criminal Code Act 1924 (Tasmania) s $2 \mathrm{~A}(2)(\mathrm{a})$ which states that a person does not freely agree to an act if they do not say or do anything to communicate consent. In terms of the actus reas, consent thus moves from being a state of mind to an act.
} 
have given prima facie consent. As noted earlier, sexual autonomy may be undermined in various ways and there may be structural or interpersonal factors which result in a complainant offering what could be described as 'apparent' consent.${ }^{97}$ Although the requirement for consent to be free, voluntary or willingly given remains a feature under affirmative standards, concern has been raised in relation to the potential for fact finders to become distracted from this 'real inquiry' when asked to look for words or conduct signalling consent. ${ }^{98}$ Thus there is a danger that the same issues, in terms of an undue focus on the complainant's actions, may emerge. Consequently, some jurisdictions prefer a 'circumstance' or 'coercion-based' model of rape, which looks to the environment within which sexual activity occurred. ${ }^{99}$ The following section will explore these models in Michigan and Italy.

\section{‘Coercion-based’ Models}

The 1974 Michigan Criminal Code (the 'Code') is one of the earliest examples of efforts to deprioritise consent within the definition of rape. The Code reframed the offence of rape as criminal sexual conduct and defined it solely with reference to a range of circumstances that, if one or more applied would render sexual contact criminal. ${ }^{100}$ These circumstances include where the victim is under 13; where the victim is under 16 and a relation to the defendant or is under the care/authority of the defendant; where the accused was armed; committing another felony; used force or coercion against the victim; threatens the victim with physical force or

\footnotetext{
${ }^{97} A C$ n 11 above.

98 See discussion in New South Wales Law Reform Commission n 93 above 42 citing A. Dyer, Preliminary Submission PCO50 [18] among others.

${ }^{99}$ For an overview of some models in European Member States see: European Institute for Gender Equality, Analysis of the National Definitions of Rape, October 2016.

${ }^{100}$ Section 750.520b, The Michigan Penal Code, 1974. The offence is also separated into 'degrees' depending on the sexual act involved.
} 
retaliation against the victim or another person or where the victim is mentally incapable, mentally incapacitated, or physically helpless. ${ }^{101}$ The Code explains that force or coercion includes, but is not limited to, instances where the defendant overcame the complainant by the application of physical force or physical violence, or where the defendant coerces the victim to submit by threatening the use of force or violence. ${ }^{102}$ Thus broadening the circumstances encapsulated within the definition. The Code's model jury instructions also note that force or coercion can involve the defendant doing something to make the complainant reasonably afraid of present or future danger which suggests the potential to capture behaviour short of physical violence. $^{103}$

Although consent does not explicitly feature in the Code's definition, discussion around the role of consent as a defence has featured in case law. It has been established that while consent cannot be raised as a defence in relation to sexual activity with a 13 years old, for example, because such a person cannot consent to sex, ${ }^{104}$ consent can be raised as a defence in relation to criminal sexual conduct by force or coercion. ${ }^{105}$ The rationale for allowing the defence of consent in the latter circumstance is due to the language of the statute which refers to the defendant 'overcoming' or 'coercing' the victim which 'implicitly required the jury to find that the complainant did not consent to sexual intercourse before it could find a defendant guilty'. ${ }^{106}$ As such, while the prosecution is not required to produce evidence of non-consent, consent can constitute an affirmative defence in some circumstances. Yet, the statute is completely silent

\footnotetext{
${ }^{101}$ Section 750.520b, The Michigan Penal Code, 1974.

102 Ibid (1)(f) (i)-(iii).

${ }^{103}$ Michigan Supreme Court, Michigan Model Criminal Jury Instructions 20.15 Use of Force or Coercion

${ }^{104}$ People v Waltonen (2006) 272 Mich. App. 678.

${ }^{105}$ Ibid.

${ }^{106}$ People v. Johnson (1993) 128 Mich. App. 618
} 
on consent, even as a defence. This gap in the law is addressed in the Code's model jury directions, where consent is defined in the following terms

[a] person consents to a sexual act by agreeing to it freely and willingly, without being forced or coerced. It is not necessary to show that the complainant resisted the defendant to prove that this crime was committed. Nor is it necessary to show that complainant did anything to lessen the danger to him/herself. ${ }^{107}$

These instructions further provide that, when deciding whether the complainant consented, the jury should take into consideration: whether the complainant was free to leave and not take part in the sexual act; whether the defendant threatened present or future injury; used force, violence, or coercion; displayed a weapon; or any other circumstance that might be relevant. If, after this analysis, there is a reasonable doubt that the complainant did consent then the defendant must be found not guilty. ${ }^{108}$

A similar coercion-based definition can be found in the Italian Penal Code. Rape, or sexual violence as it is now termed, is defined in the Italian Code with reference to the use of violence, threats, abuse of authority to coerce another to commit or submit to sexual acts; or the abuse of another's physical or psychological inferiority or deception as to the identity of the perpetrator to induce another to submit. ${ }^{109}$ Fenton has explained that violence can be physiological and that the inclusion of abuse of authority within the Italian definition is to protect those in 'a weak position in the workplace and/or the family'. ${ }^{110}$ The Italian definition also includes aggravating factors such as the victim being a minor, the use of arms, alcohol or

\footnotetext{
${ }^{107}$ Michigan Model Criminal Jury Instructions n 103 above 20.27 Consent

108 Ibid.

${ }^{109}$ Italian Penal Code 1930, Article 609bis.

${ }^{110}$ Fenton n 8 above 190.
} 
narcotics or the defendant pretending to be a public official, which would increase the sentence of the defendant. ${ }^{111}$ While this definition makes no reference to consent, the Italian Supreme Court has held that the material element of its legislation is 'the committal of any sexual act without the consent of the partner'. ${ }^{112}$ In elaborating upon the definition of rape and the issue of consent the Supreme Court emphasised that proving resistance is not required in order to prove violence, for example, as a victim may have 'yielded to put an end to an unbearable situation' ${ }^{113}$

Nonetheless, Italian law still requires that the accused's act was committed intentionally and that the accused was aware that the complainant was not consenting. Where the defendant is not aware, they cannot be found guilty. ${ }^{114}$ As such, they may be mistaken as to consent and, if so, the requirement is that their mistake be honest as opposed to reasonable. Consequently, establishing this awareness has posed difficulties where no explicit threats or violence have been used or where there is no reaction by the complainant. ${ }^{115}$ The fact that the statute provides no definition of what consent is raises the potential for problematic myths to re-enter the courts evaluations at this point. For instance, the Italian Supreme Court overturned a conviction on the basis that the complainant's hands had not been restrained while the defendant performed oral sex on her, that she had failed to manifest any objections during the encounter and that the facts did not suggest that she was 'at the mercy' of the defendant. ${ }^{116}$

\footnotetext{
${ }^{111}$ Italian Penal Code n 109 above.

${ }^{112}$ Fenton n 8 above 187, citing Cass III 3.12.1999 n. 13829.

${ }^{113}$ Ibid 189 citing Cass 16.11.1988, Mass.uff., 1988, m. 179752.

114 Ibid 191.

${ }^{115}$ See e.g., Ibid; R.A. Van Cleave, 'Rape and the Querela in Italy: False Protection of Victim Agency’ (2007) 13 Michigan Journal of Gender and Law 273.

${ }^{116}$ Van Cleave Ibid citing Corte app. di Roma, sez. tee, 12 July 2000.
} 
The coercion-based definitions outlined above speak very clearly to the negative aspect of sexual autonomy by specifically setting out abusive contexts that individuals should be protected against. The explicit inclusion of abuses of authority within Italy's definition is noteworthy in this regard. Other definitions taking this approach have been applauded due to their potential to capture the 'use of asymmetric power that one sort of agent may hold over another' ${ }^{117}$ Attention to abuses of authority thus provide the opportunity for the courts to more fully engage with the continuum of coercion outlined in section two of this article.

On first glance, it would seem that the positive dimension of sexual autonomy, i.e., the right of an individual to choose the type of sex they wish to engage in, is omitted from these coercionbased definitions. This omission means that there is no standard against which the perpetrator's actions and the victim's expression of choice (if any) can be assessed. As such, violations of sexual autonomy may only be recognised when they fall neatly into one of the explicitly accounted for circumstances. However, on further inspection consent is implicit to both these definitions, with Michigan even providing a definition of consent in its model jury instructions, accompanied by a set of questions which reflect the contextual dimension of sexual autonomy. Yet there is an important difference between the ways consent has been incorporated within the two definitions. In Michigan consent is only relevant in so far as its presence provides a defence. The assisting questions seem to narrowly interpret 'freely and willingly' by asking about escape routes and the use of violence. ${ }^{118}$ The Supreme Court in Italy, on the other hand, has made a clear statement in relation to the scope of the definition and the prohibition of all non-consensual conduct. This suggests that Italy's definition, unlike Michigan's, has

\footnotetext{
${ }^{117}$ S Anderson, 'Conceptualising Rape as Coerced Sex' (2016) 127 Ethics 50, 58.

118 See n 108 above.
} 
application outside of the circumstances already listed, ${ }^{119}$ and is more in keeping with the human rights standards outlined earlier.

Nonetheless, Carline and Easteal have argued that definitions which make no explicit mention of consent, or lack thereof, fail to reflect the 'uniquely degrading nature' of non-consensual sexual activity meaning that it, in and of itself, is a grave wrong that should be criminalised. ${ }^{120}$ The omission of explicit reference to consent within definitions of rape is problematic in light of the principle of nullum crimen, nulla poena sine lege, requiring the law to communicate, in a sufficiently clear and precise way, the prohibited conduct. ${ }^{121}$ A counter to these arguments is that the criminal nature of such conduct can become apparent, and will be foreseeable, through, for example, legal advice and reference to case law if the courts have interpreted the definition in line with human rights standards. However, there is a strong case for legislation on rape to include a provision explicitly prohibiting all non-consensual activity given the willingness of many, as evidenced through the EU survey and Italian case-law discussed above, to excuse non-consensual activity if it is unaccompanied by violence or resistance. ${ }^{122}$ Such a provision would reinforce the absence of consent as the central element of rape, with force, coercion or other abusive circumstances as only some of the means through which it may be evidenced.

\section{REFLECTIONS AND MOVING FORWARD: INSIGHTS FROM US MILITARY}

\section{LAW}

\footnotetext{
${ }^{119}$ Fenton $\mathrm{n} 8$ above at 187 for instance notes developments in case law criminalising sexual interactions that go beyond what was originally agreed or where one party withdraws consent and the other continues with the sexual act.

${ }^{120}$ A. Carline and P. Easteal, Shades of Grey - Domestic and Sexual Violence Against Women: Law Reform and Society (Oxon: Routledge, 2014) 261. See also Amnesty International n 69 and n 3 above.

${ }^{121}$ See $n 54$ above.

${ }^{122}$ European Commission n 29 above; Van Cleave n 116 above.
} 
The ECtHR and the CEDAW have both set standards in relation to the definitional parameters of the crime of rape with a view to centralising the element of consent or lack thereof. Although variations of the consent and coercion-based models suggested by the CEDAW exist in domestic jurisdictions, the consent models, such as those in the England and Wales and Canada, are preferable. Such models are preferred as they more adequately reflect rape as a violation of sexual autonomy. In doing so, these models send a clear message about the prohibition of all non-consensual sexual activity. However, an enduring challenge under this model, for judges and juries in particular, is getting the appropriate balance between the positive, negative and contextual aspects of sexual autonomy. For instance, this article has highlighted 'conceptual slippages ${ }^{123}$ between the concepts of consent, coercion and submission in the context of courts in England and Wales. Although some of the judicial discussion around these terms represents an attempt to avoid coercive overreach-by acknowledging that not all choices to have sex are aligned with romanticised notions of consent and desire — some of the language used confuses rather than clarifies the relationship between these terms. The quote from the Jeffrey, above, is illustrative here: 'submission of her free choice to a demand made physically or in words, is not the same as consent... On the other hand, an exercise of free choice, if it led to reluctant agreement, that is not the same as submission'. ${ }^{124}$ The use of the term 'free choice' in relation to both submission and reluctance may prove particularly costly in cases of non-violent coercion that sit outside what is commonly understood as 'real-rape ${ }^{125}$ and where the victim's reaction deviates from what is often viewed as 'rational'. ${ }^{126}$ Such cases may include incidents where, instead of screaming victims may comply and instead of resisting they may initiate the

\footnotetext{
${ }^{123}$ Language borrowed from Munro n 6 above 68.

${ }^{124} R \vee$ Jeffrey (2017) EWCA Crim 469 para 25-28 (emphasis added by author).

${ }^{125}$ Estrich n 24 above.

${ }^{126}$ See $n 33$ above.
} 
sexual activity. As such, there is room to sharpen the interpretative and analytical tools that judges deploy to navigate this contested, and potentially damaging, space.

In this regard, it may be useful to extend our analysis beyond human rights standards or comparisons between domestic jurisdictions, and explore whether military law can provide additional insights. The military has a system of law that is distinct to the law applicable to civilians in domestic jurisdictions, due to the hierarchical nature of the military and the institutional emphasis on discipline, obedience and loyalty. ${ }^{127}$ It is precisely because military law is designed to operate in the context of this hierarchical structure that it can deepen our analysis of the relationship between consent and coercion. Indeed, although the military represents a very obvious, formal and all-encompassing power structure, useful parallels can be made with the domestic scenarios outlined at the beginning of this paper and, in particular, with the power wielded in abusive interpersonal relationships categorised by physical, emotional or psychological abuse. ${ }^{128}$

It is acknowledged that offences aimed at capturing sexual abuse within relationships of power asymmetry or hierarchy can already be found in domestic jurisdictions, such as abuse of trust offences or those relating to careworkers in England and Wales, or the offence of sexual

\footnotetext{
${ }^{127}$ L. B. Nichols, 'The Justice of Military Justice' (1971) 12 William \& Mary Law Review 482, 484; W.T. Cox, 'Consensual Sex Crimes in the Armed Forces: A Primer for the Uninformed' (2007) 14 Duke Journal of Gender and the Law 291.

${ }^{128}$ On the latter see M Buchhandler-Raphae, 'The Failure of Consent: Re-Conceptualizing Rape as Sexual Abuse of Power' (2011) 18 Michigan Journal of Gender and Law 148 and S. Leahy, “"No Means No”, But Where's the Force? Addressing the Challenges of Formally Recognising Non-Violent Sexual Coercion as a Serious Sexual Offence' (2014) 78 The Journal of Criminal Law 309.
} 
exploitation in Canada. ${ }^{129}$ However, these offences focus primarily on the existence of a relationship of trust or case and are less concerned with striking the appropriate balance between positive and negative sexual autonomy. This is reflected in the lack of attention to the presence or absence of consent on the part of the complainant and the omission of consent as a defence. ${ }^{130}$ In the military context, on the other hand, it has been acknowledged that 'the authority structure inherent to a military organization may... strongly affect a complainant's sense of what options are realistically open to her and that when faced with a sexual advance or sexual touching by a senior-ranking officer'. ${ }^{131}$ The context thus becomes relevant to our considerations of whether a crime has occurred as opposed to being determinative of a crime, speaking to the evaluative and contextual dimension of sexual autonomy. In the US military context an interpretative tool known as the doctrine of constructive force has been utilised by military law-makers to take account of these power disparities and their potential impact on consent. According to Murphy, this doctrine 'accomplishes what other jurisdictions have, for the most part, failed to accomplish: a principled approach to criminalizing all sexual intercourse which is coercive and unwanted'. ${ }^{132}$ As such, the doctrine of constructive force will be explored in more detail below and consideration will be given to whether it has anything to offer its domestic counterparts.

\footnotetext{
${ }^{129}$ Section 16-24 and sections 28-44 Sexual Offences Act n 72 above; Section 153(1) Canadian Criminal Code n 86 above.

${ }^{130}$ See Section 150. 1(1) Canadian Criminal Code n 86 above.

${ }^{131}$ M. Deschamps, External Review into Sexual Misconduct and Sexual Harassment in the Canadian Armed Forces, External Review Authority, March 27, 2015 recommending additional guidance on consent to address the potential impact of difference in rank and chain of command on genuine consent, at www.forces.gc.ca/en/cafcommunity-support-services/external-review-sexual-mh-2015/definitions.page (last accessed 23 May 2018) (emphasis added by author).

${ }^{132}$ Murphy n 15 above.
} 
The doctrine of constructive force was originally developed by military appellate courts as a means to overcome the problems associated with early definitions of rape in the Manual for Courts Martial, which required both proof of force and of the absence of consent. ${ }^{133}$ These early definitions of rape required some manifestation of resistance and inferred consent where resistance was absent. ${ }^{134}$ The doctrine of constructive force meant that the force involved in penetration established both the elements of force and the absence of consent where a victim was found to have been incapable of resistance. Examples included where the victim lacked the mental or physical faculties to resist, or where resistance would have been futile due to a fear of death or great bodily harm. ${ }^{135}$ In relation to the latter example, a 'totality of the circumstances ${ }^{\prime 136}$ approach is applied wherein 'all the surrounding circumstances are to be considered in determining whether a woman gave her consent, or whether she failed or ceased to resist only because of a reasonable fear of death or grievous bodily harm'. ${ }^{137}$

Interestingly, the doctrine of constructive force has been used in military case law where the parties' difference in rank or position in the chain of command may have impacted the

\footnotetext{
${ }^{133}$ See United States v. Kernan, 11 C.M.R. 314, 321 (C.M.A. 1954). See also Manual for Courts-Martial, 1984 Ed., Part IV, 76: Article 120 '(a) Any person subject to this chapter who commits an act of sexual intercourse with a female not his wife, by force and without her consent, is guilty of rape and shall be punished by death or such other punishment as a court-martial may direct'

${ }^{134}$ See Manual for Courts-Martial, Ibid, 76 - 'If a woman in possession of her mental and physical faculties fails to make her lack of consent reasonably manifest by taking such measures of resistance as are called for by the circumstances, the inference may be drawn that she did consent'.

${ }^{135}$ Ibid, 76-77.

${ }^{136}$ Described as such in United States v. Clark, 35 M.J. 432, 435(C.M.A. 1992).

${ }^{137}$ Manual for Courts-Martial n 133 above, 77.
} 
complainant's ability to manifest resistance or give genuine consent. The application of the doctrine in this context raises interesting issues in relation to its scope, as well as the interplay between force, consent and resistance. Take for instance the 1989 case of United States v Bradley, which was heard by the US Court of Military Appeals, where the appellant was the drill instructor of the victim's husband. ${ }^{138}$ The appellant had arrived at the victim's home late at night when her husband was away on duty. He threatened to imprison the victim's husband for three years for violation of orders, if she did not comply with his sexual demands. The Court of Military Appeals found that although no threats of harm were made against the victim and no physical force used, the 'military relationship with its ancillary implications for the dependant spouse created a unique situation of dominance and control where explicit threats and display of force by the military superior were not necessary'. ${ }^{139}$ Indeed, the Court stressed that the appellant had 'exploited his imposing status as drill instructor' by 'employing language indicting his power and control' ${ }^{140}$ Thus, it would seem that the Court was less concerned with fear of bodily harm, which is one justification for the application of the constructive force doctrine, than with the status of the drill instructor and his ability, which he made clear to the victim, to follow through with his threat. As this case shows, the doctrine of constructive force allows the court to bring to the fore the pervasive power dynamics inherent in some environments or relationships that can undermine not only the ability to consent but also the ability to refuse.

The US Court of Military Appeals ruled on the doctrine of constructive force again in the 1992 case of United States $v$ Clark $^{141}$ where the appellant, Sergeant Clark, was the direct supervisor

\footnotetext{
${ }^{138}$ United States v. Bradley, 28 M.J. 197, 200 (C.M.A. 1989).

139 Ibid.

140 Ibid.

${ }^{141}$ United States v. Clark, 35 M.J. 432, 436 (C.M.A. 1992)
} 
of the victim. The appellant ordered the victim to accompany him to a storage shed to get supplies, the victim entered the shed and the appellant closed the door behind them. The appellant then 'grabbed' the victim and told her take down her trousers. ${ }^{142}$ The victim testified that she had been scared of the appellant and unbuttoned only the top two buttons on her trousers in the hope that he would be unable to remove her trousers, however this was not the case and he proceeded to have intercourse with her. The victim did not actively resist, though her body stiffened as a result of fear.

In response to the appellant's claim that there was no force, the Court of Military Appeals declared that a Sergeant 'cannot create by his own actions an environment of isolation and fear and then seek excusal from the crime of rape by claiming the absence of force [...] especially where, as [in Clark], passive acquiescence is prompted by the unique situation of dominance and control presented by appellant's superior rank and position'. ${ }^{143}$ However, the superiorsubordinate relationship was just one factor in determining force and lack of consent. As noted by the Court of Military Appeals in this case, if superior rank alone was enough to establish constructive force, 'all of the significant number of sexual fraternization cases that reach this Court could conceivably come here as rape convictions rather than fraternizations'. ${ }^{144}$ In Clark, constructive force was demonstrated through various factors including, for example, the accused ordering the victim to an isolated location which was out of view of anyone else in the training unit. The need for something more than a hierarchical relationship can be seen as an attempt to set the boundaries of the constructive force doctrine in a way that is sensitive to both the positive and negative aspects of sexual autonomy. Indeed, to indiscriminately label sexual

\footnotetext{
${ }^{142}$ Ibid.

${ }^{143}$ Ibid., 436

${ }^{144}$ Ibid.
} 
interactions between superior and subordinates as rape would be overly paternalistic and it would threaten, rather than protect, autonomy.

The use of constructive force was again emphasized in the 1995 case of United States v McCreary, before the Air Force Court of Criminal Appeals. Here a military training instructor approached a trainee for sex, telling her that his superior condoned his sexual activity with trainees and that he would make her repeat basic training if she refused. ${ }^{145}$ The trainee had sex with the appellant on a number of occasions, the Court of Criminal Appeals finding that this was due to the appellant's threat in relation to the training, to the appellant's statements that he knew people in high places who would pursue any trainees who crossed him throughout their careers, and because the trainee felt she had no avenue of redress. In upholding the appellant's conviction the Court of Appeal explained

This is a case about sexual activity between a female basic trainee and her male military training instructor-a person cloaked by regulation, custom, and practice with the authority over practically every aspect of her daily existence. More specifically, he held the awesome (to a basic trainee) power of "recycling"-of requiring the trainee to repeat basic training. To anyone who has been through this or a similar regimen, the terror inspired by the threat of having to go through it again is very real. ${ }^{146}$

This statement reflects a 'totality of circumstances' approach which is required under the doctrine of constructive force. As noted earlier, this approach requires consideration of the surrounding circumstances to determine the victim's mindset. While this approach may open up the possibility of a negative focus on the victim's conduct, Murphy explains that the focus under this doctrine "is not grounded in "hostility" toward the victim, but rather it is based upon

\footnotetext{
${ }^{145}$ United States v McCreary, WL 77637, 1995.

${ }^{146} \mathrm{Ibid}, 86$.
} 
an evidentiary analysis of those factors which make a particular act of intercourse coercive and unwanted'. ${ }^{147}$ Such an evidentiary analysis is demonstrated in McCreary through the Court's emphasis on the trainee's perception of the power held by the training instructor and its potential effect on her. Also of significance is the Court's acknowledgement that the encounter was coercive and oppressive not only because of potential physical harm i.e., 'recycling', but also because of the potential for career related harms and other harms associated with daily life in the military.

So, key principles that can be derived from the case law are the need to show the use of inequality, hierarchy or control to compel, rather than their mere existence, and the need to engage in a thorough analysis of the background circumstance. Tailored judicial instructions on constructive force contained within Military Judges Benchbook reiterate these principles. ${ }^{148}$ The instructions provide that where there is evidence that 'the accused used or abused his military position and/or rank and/or authority in order to coerce and/or force the alleged victim to have sexual intercourse', ${ }^{149}$ such evidence forms part of the 'surrounding circumstances you may consider in deciding whether the victim consented' ${ }^{150}$ The doctrine is thus of significant normative and legal value as it acknowledges the way in which power, control and dominance can be asserted by one party over another to compel compliance, and that explicit threats and displays of force may be unnecessary in some relationships/circumstances.

\footnotetext{
${ }^{147}$ Murphy n 15 above.

148 See Department of the Army Pamphlet 27-9, Military Judges Benchbook, September 2002, 430: Note 6" constructive force - use of military power'. Same provision contained 2010 and 2014 versions of the Benchbook. ${ }^{149}$ Ibid. 431 (emphasis added by author).

${ }^{150}$ Ibid.
} 
The doctrine was applied and broadened further in the 2005 case of United States $v$ Terry, decided by the US Court of Appeals for the Armed Forces. ${ }^{151}$ The victim in this case was an Airman First Class (AIC) officer and the appellant was a radiology technician working in the Hospital of the Air Force Base. The appellant performed an ultrasound examination on the victim and asked her to return the next day as a volunteer so he could take ultrasound photos of the veins in her arms for his studies. When she returned the next day the clinic was relatively deserted. The appellant raped the victim in the examination room. In rejecting the appellant's claim that a direction on constructive force was not appropriate in this case Judge Fincher explained:

While the appellant did not have an improper NCO/trainee relationship with A1C S, the totality of the circumstances reveals an environment that was just as coercive. The appellant created an atmosphere of trust [...] He then systematically isolated her in a small examination room where he used his expertise as an ultrasound technician to dominate and control her. ${ }^{152}$

This case is therefore significant because it suggests that the doctrine of constructive force is broader in scope than initially thought. While there was no disparity in rank between the two parties in this case, the doctrine was applied due to the coercive environment created by the appellant, the compelling effect of which was held to be analogous to the abuse of power held by superiors. The case therefore suggests that the doctrine may be applied not only in cases

\footnotetext{
${ }^{151}$ United States v. Keith M. Terry, ACM 358016 December 2005, 4. 'NCO' stands for Non-commissioned officer. A non-commissioned officer is an enlisted member of the armed forces holding a position of some degree of authority.

${ }^{152}$ Ibid.
} 
with the potential for coercion due to a formal pre-existing relationship but also when the perpetrator designs a relationship or atmosphere for the purpose of control and coercion.

The way the doctrine of constructive force has been applied in the military cases to identify coercive relationships or atmospheres; to take account of the complainant's perception of the power held by the accused; and the way this coercion impacts the victim's ability to consent is promising. In thinking through the doctrine's domestic relevance, the Terry and McCreary cases in particular are interesting. Indeed, in domestic settings, rather than power being formally invested in someone as is often the case in the military, such power can be strategically gained, as it was in Terry. This may be achieved over time through tactics of coercive control as discussed earlier in this article. The abuser may, as was the case in McCreary for example, take action that negatively affects the daily life of the complainant. While the actions taken in McCreary were military specific an abuser in domestic settings might isolate the complainant, control their movements, their finance and/or their interactions with their children. In promoting a 'totality of circumstances' approach, the doctrine of constructive force may help to capture these informal coercive dynamics and how they are perceived by the complainant. However, the narrow threshold upon which the doctrine of constructive force is based - fear of physical injury and resistance being futile -has re-emerged in more recent case law.

In the 2008 case of United States v Bright, ${ }^{153}$ which is strikingly similar on the facts to the McCreary case above, a drill sergeant had his conviction for the rape of a female trainee overturned on appeal. In this case, the parties met at various hotels for sex, at the defendant's request. The complainant explained that on some occasions, 'I just kind of laid there and didn't really do much of anything', but at other times, the defendant was explicitly abusive,

${ }^{153}$ United States vBright, 66 M.J. 359, 362-66 (C.C.A.F. 2008). 
sodomising her while she tried to resist. ${ }^{154}$ The accused did not appeal his conviction for the latter crimes because the complainant had verbally or physically demonstrated her lack of consent. Regarding the other instances of sexual activity, the Court of Appeal noted that 'any similar manifestations of lack of consent' were missing, and it emphasised that the complainant had verbally agreed to meet the defendant and independently travelled to the hotels. ${ }^{155}$ The Court of Appeals went on to consider whether resistance would have been futile but found that the record 'could not support a finding that resistance was overcome by threats of death or grievous bodily injury'. ${ }^{156}$ This is despite evidence of the drill sergeant asserting that he had control over her on numerous occasions and threatening to put her on 'lock down' for eight months. Moreover, there was evidence before the Court of Appeals that the complaint was afraid of the sergeant due to his position, physical size and his previous statements to her indicating his capacity for violence; and that the drill sergeant had subjected the whole platoon to rigorous physical training, and what could be described as punishment after she previously rejected his advances, with the Court of Appeal acknowledging that the drill sergeant's conduct amounted to an 'egregious abuse of his position'. 157

Nonetheless, we should not lose sight of the doctrine's significance, as developed over the earlier military cases and the wider potential it offers in relation to the impact of coercive relationships on sexual autonomy and expressions of consent or lack thereof. So, the question now is, how can the pre-Bright conception of this doctrine aid the approaches in domestic jurisdictions explored above? As discussed, both consent and coercion-based approaches to rape acknowledge that consent must be free and voluntary. It could therefore be argued that

\footnotetext{
${ }^{154}$ Ibid, 6.

155 Ibid, 15.

${ }^{156}$ Ibid, 18

${ }^{157}$ Ibid, 16-20.
} 
there is already scope to factor in the impact of power, control and dominance within these existing models. However, it is suggested that the constructive force doctrine has the potential to reframe these current inquiries to better reflect the nature and impact of the perpetrator's wrongful act. In particular, the doctrine may help to direct the court or the jury's attention to the actions of the perpetrator while avoiding the conceptual slippages which result from focusing on the actions or inactions of the complainant. This will be demonstrated by revisiting the Bright case and considering how the reasoning and analysis might differ under each approach. The Bright case is used as it draws out some of the issues identified earlier in relation to how dominant perceptions of what amounts to 'real-rape' and how a 'real' victim should react problematically impact the application of both the consent-based and coercion based models.

In considering the coercion-based approach first, the reasoning under this model might mirror the Bright decision. For instance, the scenario outlined in Bright may fall under the 'use of force or coercion' category of sexual misconduct under the Michigan Criminal Code. Although the definition of force or coercion references the application or threat of physical force it may be argued that Bright's previous statements placed the complainant in fear of future danger as is provided under the jury instructions. If the prosecution were successful at this, the defence may argue that the complainant consented; drawing in particular on the fact that she was 'free to leave and not take part in the sexual act'. ${ }^{158}$ Under Italian law it is likely that, even though abuse of power is part of the definition and flagged up with the acknowledgement that a person may 'yield' ${ }^{159}$ the lack of physical or situational restraint placed on the victim during the

\footnotetext{
${ }^{158}$ See n 108 above.

159 See n 113 above.
} 
encounter, and her failure to express her lack of consent under these circumstances, may again be used to argue that the defendant could not have known that the victim was not consenting.

In turning to the consent-based models, the prosecution would not be restricted to fitting the Bright scenario within one of the specified presumptions or consent-negating circumstances. It could instead base its case on a lack of consent on the part of the complainant. The ability of the prosecution to do this is one of the reasons why this article has favoured legal models that explicitly address the issue of consent, or lack thereof, in their definitions. The prosecution would likely advance evidence relating to the statements and threats used by Bright to show that the victim could not freely and willingly agree to the encounter and that Bright could not have reasonably believed that she consented. On the above facts, this would likely be a case where an instruction on the difference between consent and submission (as provided for in the England and Wales context) would be helpful, with the latter being 'Where...a person gives in to something against his/her free will'. ${ }^{160}$ In England and Wales, the judge may also explain that while consent may be given 'enthusiastically...in other circumstances it is given with reluctance, but nevertheless it is still consent'. ${ }^{161}$ This will be a matter for the jury to consider and it would depend on its willingness to view the defendant's conduct as encroaching on the complainant's free will, or whether, while it is something that the complaint does not really want to do, she reluctantly agrees. In terms of the defendant's belief in consent the jury would be asked to consider whether that belief was reasonable. In doing so it would be asked to consider whether an ordinary reasonable person in the same circumstances as the defendant would have believed the complainant was consenting. ${ }^{162}$

\footnotetext{
${ }^{160}$ See n 78 above.

${ }^{161}$ Ibid.

${ }^{162}$ Ibid, 18.
} 
Under Canadian law, the jury may be asked to consider "whether (the defendant) honestly believed that (the complainant) effectively said yes through his/her words or actions'. ${ }^{163}$ Although there is evidence that the complaint just 'lay there' through some of the encounters, her actions in speaking with the defendant, planning their encounters and turning up may be used to show she was exercising 'free will' or, if is determined that she was not exercising free will, it may nonetheless be argued that the defendant could not have been aware of this, thus his belief in consent was reasonable.

It is true that the above simply sets out potential arguments under each approach and that it cannot be said for certain what a particular jury or judge would decide. It may be that they would find the defendant's conduct criminally wrongful because the evidence demonstrates that coercion was used, that the complainant did not consent and that the defendant would have been aware of this. It is equally true that, due to the perennial problem of agreeing on the exact level of oppression or coercion that must be exerted over another person to warrant criminal sanction, the judge or jury may find, as the US Military Court of Appeals did, that although the defendant's conduct was wrong and immoral it is not criminal. It is not suggested here that the application of an earlier conception of doctrine of constructive force would eliminate these difficulties. Rather, it is suggested that some of the vocabulary from these earlier cases can progressively reshape inquiries in a way that allows us to engage more effectively with the context in which sexual interactions take place.

For instance, in terms of the actus reus the focus on whether the complainant submitted, was overcome, reluctantly agreed, or expressed her lack of consent directs our evaluative lens on the complainant. The risk is of obscuring and failing to make explicit the perpetrator's role. Earlier, pre-Bright, conceptions of the constructive force doctrine, on the other hand, can

\footnotetext{
${ }^{163}$ See $n 90$ above.
} 
address this by asking whether the 'accused used or abused his military position or authority in order to coerce and/or force the alleged victim to have sexual intercourse'. ${ }^{164}$ Alternatively, the question could be whether the accused used or abused his military position or authority in order to restrict the complainant's freedom to make a choice. The framing of these questions removes the temptation to focus on dissecting the complainant's behaviour or reaction, and now more explicitly forces an interrogation of the accused's behaviour and its impact on the complainant's free will. In terms of mens rea, instead of asking how the circumstances or the complainant's words or conduct may have led the accused to reasonably believe in consent, the central question would be whether the accused was aware of, or contributed to, an environment of coercion, or in language adopted from Bradley and Clark'a unique situation of dominance and control'165 in which the complainant's free will was restricted and whether, in light of that, it was reasonable for him to believe in consent.

As this article has asserted a preference for domestic consent-based models, it is worth now considering what potential these insights from the doctrine of constructive force have in terms of improving/reframing such models. This potential can be demonstrated by returning to the domestic abuse example given at the beginning of this article, where a woman anticipates physical abuse from her partner and initiates sexual intercourse as a protection strategy. Under the current legal frameworks in force in both England and Wales and Canada, it would be easy to lose sight of the backdrop of abuse within which this sexual encounter took place when addressing questions around consent. This is because the law in both England and Wales and Canada invite oversimplified evaluations of the encounter. For example, if this case were to come before a jury under the law in England and Wales, the judge may give the jury a direction

\footnotetext{
${ }^{164}$ See $\mathrm{n} 149$ above (emphasis added by author).

165 See n 139 and 143 above.
} 
on fear i.e., stating that 'when a person is so overcome by fear that he/she lacks any capacity either to give consent or to resist, that person does not consent but is submitting to what takes place'. ${ }^{166}$ However, the initiation of sexual contact by the complainant challenges traditional understandings of submission as expressed in this type of instruction. Indeed, it is scenarios such as this, where an individual may appear to be consenting, that led to problematic language such as 'willing submission' being used by courts in England and Wales. ${ }^{167}$ Similarly, under Canadian law, when determining the accused's belief in consent, consideration would have to be given to whether the complainants words or actions effectively led the accused to believe she said yes. Against this background, the constructive force doctrine offers valuable insights for both jurisdictions.

Drawing from the constructive force doctrine and amending the language slightly to reflect civilian contexts, the process of evaluating consent in this example could benefit from questions such as 'Did the accused create an environment of coercion or a situation of dominance and control within which the complainant's freedom to make a choice was restricted?'; and 'Was the accused aware of this environment and its potential impact on the complainant's free will?'. It is important to remember that these questions would not replace the elements of rape as provided under the consent models, rather they would replace current analytical tools, such as those embodied in jury instructions discussed above. Therefore, while current laws are framed to encourage a contextual approach, this is too often used to bolster defendant's claims of belief in consent on the basis of the complainant's actions or inactions rather than exploring how the context and the accused's use of that context (which may already exist or was strategically created) affected the complainant's ability to control intimate contact.

\footnotetext{
${ }^{166}$ See $\mathrm{n} 78$ above.

${ }^{167}$ Kirk n 81 above.
} 


\section{CONCLUSION}

The question of what 'counts' as rape and how it should be legally defined evokes controversy and contestation. ${ }^{168}$ However, if rape is to be understood as a violation of sexual autonomy, with the protection of sexual choice at the centre, then it is essential that this is reflected in the definition. Although this may be achieved by centralising the concept of consent within definitions of rape, the protection of sexual autonomy requires an appreciation of the range of behaviours, beyond physical force, that may undermine autonomy and thus constitute rape. In this regard, it is essential that definitions of rape are designed in a way that facilitates engagement with what Munro has termed the 'profoundly messy contexts' within which sexual decision making occurs. ${ }^{169}$ This article thus set out to consider whether the consent-based and coercion-based models for defining rape that exist in domestic jurisdictions are capable of such a contextual approach. Drawing from definitions in England and Wales and Canada as examples of consent-based models and Michigan and Italy as examples of coercion-based models, it was found that a contextual element is built into both approaches through, for example, their emphasis on sexual encounters being 'freely', 'willingly' or 'voluntarily' agreed to. ${ }^{170}$ However, the models that make this aspect explicitly clear through definitional inclusion, such as the England and Wales and Canada, are to be preferred as they have the potential to capture more violations of sexual autonomy than those that only implicitly recognise this feature.

\footnotetext{
${ }^{168}$ B.M., McKimmie, B.M. Masser, and R Bongiorno 'What Counts as Rape? The Effect of Offense Prototypes, Victim Stereotypes, and Participant Gender on How the Complainant and Defendant are Perceived' (2014) 29(12) Journal of Interpersonal Violence 2273.

${ }^{169}$ Munro n 6 above 46.

${ }^{170}$ See e.g., Section 74 Sexual Offences Act n 72 above; Section 273.1 (1) Canadian Criminal Code n 86 above; Michigan Jury Instructions n 107 above.
} 
While attention to context gives the appearance of progress, a core difficulty is ensuring that the analysis remains focused on the key questions of whether there was the opportunity for the complainant to exercise free choice and the defendant's awareness or role in this. Indeed, this article has demonstrated that the questions used to frame the analysis of context often result in the victim being 'put on trial' ${ }^{171}$ with the potential for problematic perceptions surrounding who may legitimately be labelled a 'real' victim dominating the discussion. ${ }^{172}$ In this regard, it is important to acknowledge that the law may sometimes act as a source of harm rather than redress. This reality has led Smart to warn that "we should not make the mistake that law can provide the solution to the oppression that it celebrates and sustains'. ${ }^{173}$ At the same time, however, victims continue to engage with the criminal justice process. ${ }^{174}$ Thus, rather than abandoning the criminal law, efforts can be made to 'improve the legal story of rape' and the treatment of the complainant. ${ }^{175}$ This article took up this task by drawing from the doctrine of constructive force which has been utilised in the US military context and arguing that it has the potential to progressively reframe our contextual and evaluative inquires. This doctrine directs attention to the perpetrator's use, abuse or creation of a coercive environment and it thus asks questions that require judges and juries to think outside of narrow paradigms, rather than reinforce them.

\footnotetext{
${ }^{171}$ M. Maynard, Violence Against Women' in D. Richardson, V. Robinson and J. Campling, Introducing Women's Studies: Feminist Theory and Practice (London: Macmillan 1993) 116.

${ }^{172}$ Estrich n 25 above.

${ }^{173}$ C. Smart, Feminism and the Power of Law (London: Routledge 1989) 49

${ }^{174}$ See $n 37$ above.

175 W. Larcombe, 'Falling Rape Conviction Rates: (Some) Feminist Aims and Measures for Rape Law' (2011) 19 Feminist Legal Studies 27, 34.
} 